\title{
Fluorine F 18 Fluorocholine
}

National Cancer Institute

\section{Source}

National Cancer Institute. Fluorine F 18 Fluorocholine. NCI Thesaurus. Code C78479.

A radiotracer consisting of methylcholine labeled with the positron-emitting radioisotope fluorine $\mathrm{F} 18$ (18F-FMCH) with potential imaging use. Upon administration, 18Ffluoromethylcholine incorporates into tumor cells through an active, carrier-mediated transport mechanism for choline and then is phosphorylated intracellularly by choline kinase, an enzyme frequently upregulated in human tumors, yielding phosphoryl 18Ffluoromethylcholine. In turn, phosphoryl 18F-fluoromethylcholine is integ rated into phospholipids in the cell membrane as part of phosphatidylcholine. As the proliferation of cancer cells is much higher than normal cells, tumor cells exhibit an increased rate of 18FFMCH uptake and incorporation, allowing tumor imaging with positron emission tomog raphy (PET). 